\title{
COMPARATIVE GLACIER PHOTOGRAPHS FROM NORTHERN ALASKA
}

\author{
By Thomas D. Hamilton
}

(Department of Geology, University of Wisconsin, Madison, Wisconsin, U.S.A.)

\begin{abstract}
Early photographs of a cirque glacier complex in the Arrigetch Peaks of the south-central Brooks Range date from $\mathrm{I} 9 \mathrm{I}$, and are the second oldest known set of glacier photographs from northern Alaska. Matching photographs and supplementary observations made in 1962 indicate that changes over the past $5^{\mathrm{I}} \mathrm{yr}$. in this area include general glacial recession and thinning, the emergence of pronounced trimlines and partial melting of ice cores beneath recent moraines.

Renewed post-hypsithermal glacial activity in the Arrigetch Peaks area attained two maxima in the recent past. The younger moraines lie close to glacier positions shown in the IgI I photographs, contain ice cores which extend practically to their surfaces and were probably formed in the latter part of the nineteenth century. More weathered deposits, underlain by ice cores at relatively greater depths, were formed at some unknown earlier date. The moraines are correlated with the two-substage recent Fan Mountain advance of northern Alaska and may correspond to dated mid-eighteenth century and middle to late nineteenth century advances of alpine glaciers in the north Pacific coastal mountains of North America.
\end{abstract}

RÉsumé. Comparaison de photographies de glaciers du Nord de l'Alaska. Des photographies anciennes d'un complexe d'un glacier de cirque, Arrigetch Peaks, Brooks Range, dates de 1911 , et sont le deuxième plus ancien jeu de photographies de glaciers du nord de l'Alaska. Des photographies répétées et des observations supplémentaires faites en 1962 indiquent que pendant les 51 années passées cette région présente un retrait général des glaciers, une nette émergence des lignes de sédiments et la fonte partielle des noyaux de glace dans les moraines récentes.

Dans les Arrigetch Peaks, le renouveau de l'activité glaciaire post-hypsithermale passa par deux maxima

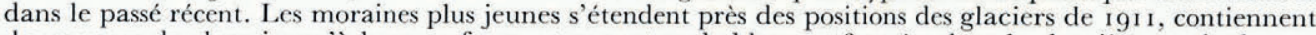
des noyaux de glace jusqu'à leurs surfaces, et se sont probablement formées dans la dernière partie du ige siècle. Des dépôts plus érodés avec des noyaux de glace plus profonds ont été formés à une date inconnue plus ancienne. Les moraines sont mises en corrélations avec les deux sous-périodes de la récente avance de Fan Mountain du nord de l'Alaska et pourraient correspondre aux avances des glaciers datées du milieu du ige siècle et de la première partie du rge siècle dans les chaînes cotières du Pacifique de l'Amérique du Nord.

Zusammenfassung. Photographische Vergleichsaufnahmen von Gletschern in Nord-Alaska. Frühere Photographien einer Gruppe von Kar-Gletschern in den Arrigetch Peaks im Südteil der zentralen Brooks Range stammen von r91 1: sie sind der Zweitälteste Satz von Gletscher-Photographien aus Nord-Alaska, der bekannt ist. Vergleichsaufnahmen und ergänzende Beobachtungen aus dem Jahre 1962 zeigen, dass die Veränderungen wahrend der letzten $5 \mathrm{I}$ Jahre in diesem Gebiet einen allgemeinen Gletscherrückgang und -schwund, die Bildung ausgeprägter Randlinien und die Abschmelzung von Eiskernen unter jungen Moränen umfassen.

Neuerliche nachwärmezeitliche Gletschervorstösse in den Arrigetch Peaks erreichten in der jungeren Vergangenheit zwei Maxima. Die jüngeren Moränen liegen nahe an den Gletscherständen, die in den Photographien von I 9 I I festgehalten sind; sie enthalten Eiskerne, die bis dicht unter ihre Oberfläche reichen, und wurden vermutlich zu Ende des i 9. Jahrhunderts gebildet. Stärker verwitterte Ablagerungen mit Eiskernen in relativ grösserer Tiefe entstanden zu einem früheren, unbekannten Zeitpunkt. Die Moränen lassen sich dem zweiphasigen jungen Fan Mountain-Vorstoss von Nord-Alaska zuordnen und mögen Vorstössen alpiner Gletscher in den nordpazifischen Küstenbergen von Nordamerika entsprechen, die in die Mitte des 18 . Jahrhunderts und in das mittlere bis späte 19. Jahrhundert datiert sind.

\section{INTRODUCTION}

Early investigations in the Brooks Range of northern Alaska were generally of a reconnaissance nature, involving rapid traverses of the principal drainage systems and very little exploration of the surrounding highlands. At the conclusion of an extensive U.S. Geological Survey reconnaissance project, which spanned the first three decades of this century, only three glaciers had been seen in all of north-western Alaska (Smith and Mertie, 1930, p. 37). Knowledge of the higher parts of the eastern Brooks Range was at this time essentially limited to a report of the explorations of Leffingwell ( 1919 ) shortly after the turn of the century.

Only two sets of early photographs of Brooks Range glaciers are known to exist today. The oldest set was taken in 1907 by Leffingwell near the head of the Okpilak Valley in northeastern Alaska (c. lat. $69^{\circ} 1^{\prime}$ N., long. $144^{\circ}{ }^{\circ}$ ' W.). Several of Leffingwell's photographs are reproduced in a recent report by Sable ( I96I), who compares their indicated ice distribution with that of the present time. A second set of photographs was taken in July I9I I by 
P. S. Smith, during U.S. Geological Survey exploration of the Alatna and Noatak Valleys in the central and western Brooks Range (Fig. I). Two of Smith's photographs, which show a cirque glacier complex at lat. $67^{\circ} 12^{\prime} \mathrm{N}$., long. $154^{\circ} \mathrm{I} 2^{\prime} \mathrm{W}$. in the Arrigetch Peaks west of the Alatna Valley, are of particular importance for their fine detail of ice distribution and thickness. The writer was able to re-locate Smith's camera stations and take matching photographs during a visit to this area in the summer of 1962 .

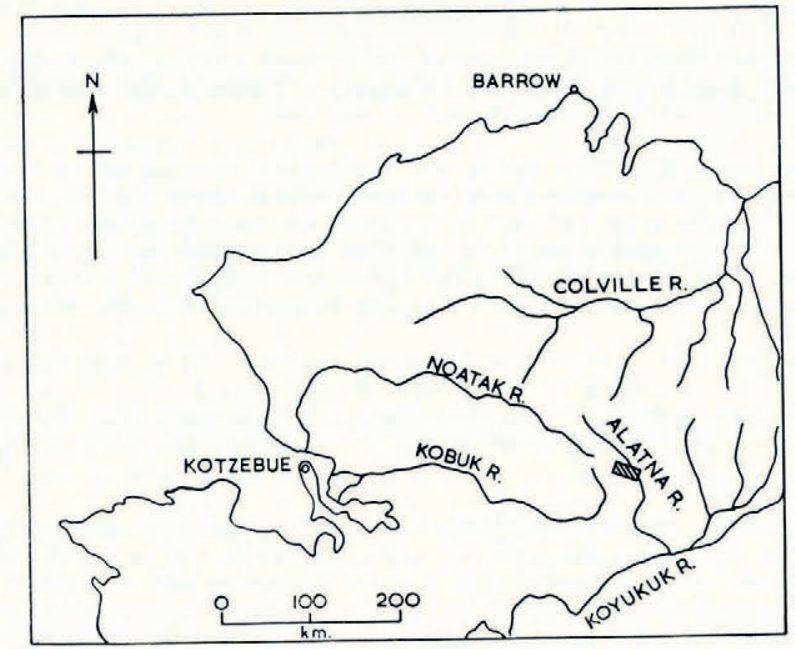

Fig. I. North-western Alaska. Principal drainages and location of detail map (hatched rectangle)

\section{The Arrigetch Peaks Area}

The Arrigetch Peaks mark the eastern limit of a granitic intrusion which stands today as a rugged highland mass between the drainages of the Alatna and the upper Kobuk and Noatak Rivers (Fig. I). Although few of its peaks exceed 2,000 m. in elevation, the Arrigetch Peaks granites rise high above the surrounding mountains and contain probably one-quarter of the presently active glaciers in the western half of the Brooks Range.

Flowing eastward to the Alatna Valley, Arrigetch Creek and an unnamed stream to the south carry the melt water of six active and five stagnant glaciers (Fig. 2). The subdued appearance of most of these ice bodies contrasts strongly with the fresh moraines, trimlines and outwash remnants which indicate much greater glacial activity and extent in the recent past. Presently active glaciers flow from elevations around $\mathrm{I}, 800 \mathrm{~m}$. down to about $\mathrm{I}, 250 \mathrm{~m}$., stagnant ice bodies lie between I, 500 and $\mathrm{I}, 200 \mathrm{~m}$., and protalus ramparts are forming today between $1,35^{\circ}$ and $\mathrm{I}, \mathrm{I} 5^{\circ} \mathrm{m}$. elevation. Fresh deposits farther down the valleys indicate that both glacial and protalus activity extended to about $300 \mathrm{~m}$. lower elevation within the past several centuries.

\section{Early Investigations and Photographs}

The only reported study of the Arrigetch Peaks area prior to I962 is that of P. S. Smith in the summer of I91 ( Smith, I912; Smith and Mertie, I930, p. 8). On I6 July of that year Smith and a companion explored Arrigetch Creek, searching for a route westward to the Noatak River. Instead of the low pass which was reputed to lie at the valley head, they found their route blocked by the head walls of an extensive cirque complex which contained several glaciers. Smith took four photographs of active and stagnating ice in this area from two stations. 
Two of Smith's photographs (Nos. 567 and 568; Table I) are views of the valley head and principal terminal moraine, taken from the flood plain of Arrigetch Creek (station I-62, Fig. 2). The pictures duplicate each other with respect to the glacial coverage. Two additional photographs were taken from the threshold of a hanging cirque valley (station 2-62, Fig. 2) just west of the initial station and at about $300 \mathrm{~m}$. higher elevation. These photographs (Nos. 570 and 57 I, Table I) form a panoramic view from the valley's head wall to a position along its eastern flank. Only a small amount of glacial ice is visible in photograph $57 \mathrm{I}$, and this is an overlap and duplication of the extreme down-valley limit of the glacial coverage of photograph 570 .

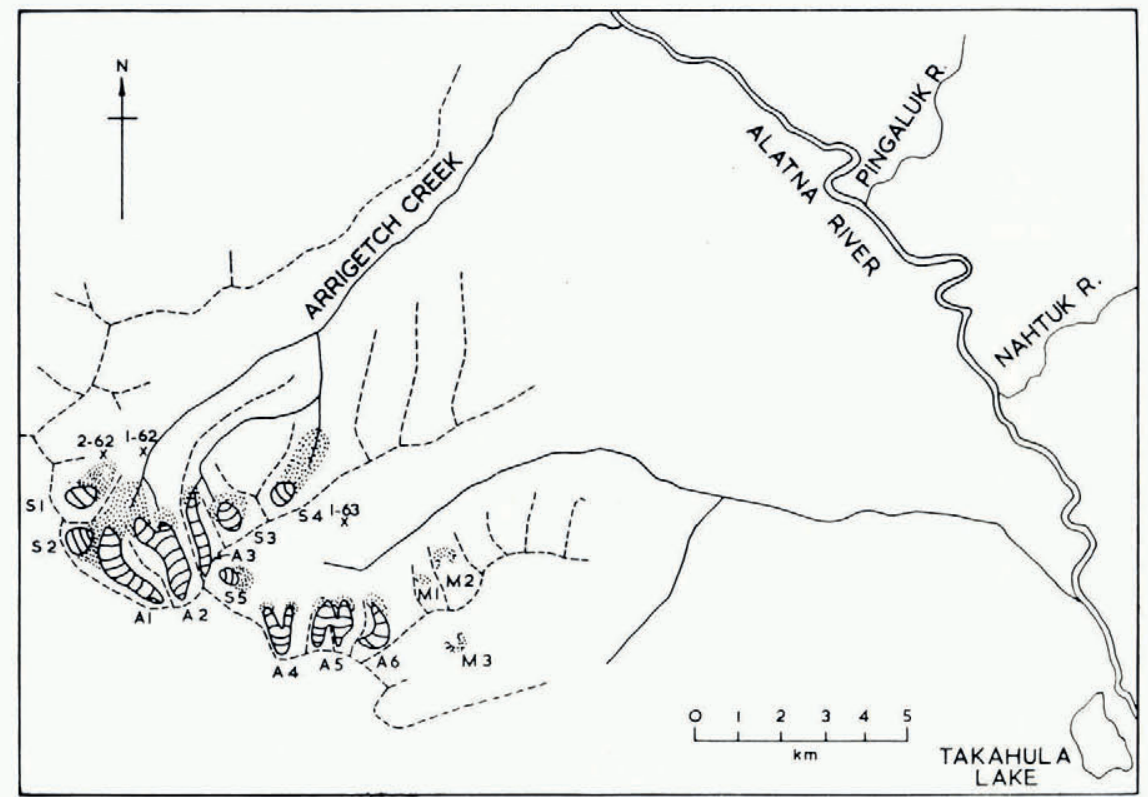

Fig. 2. Glaciers and drainage of the eastern Arrigetch Peaks. Major ridge lines are dashed. Recent glacial deposits are shown as dotted areas in front of the active $(A)$ and stagnant $(S)$ ice bodies. Ice has disappeared from the vicinity of three recent moraines $(M)$. With the exception of Wichmann Glacier $\left(A_{3}\right)$, ice and moraine nomenclature is for descriptive purposes only. Crosses mark camera stations, and the associated numbers are those under which photographs are filed at I.G.Y. World Data Center A

Table I. Early Glacier Photographs from North-western Alaska (On file at the U.S. Geological Survey Photograph Library, Denver, Colorado)

File number

P. S. Smith, $5^{67}$

P. S. Smith, 568

P. S. Smith, 570

P. S. Smith, 57I

P. S. Smith, 598

\section{Title}

Glacier at head of False Pass Creek, Alatna District, Alaska. I6 July i 9 I 1 .

Same as No. $5^{67}$.

Glacier at head of False Pass Creek from northern cirque. Alatna District, Alaska. I6 July igir.

Same as No. 570 .

Big snow dome south of Noatak near camp. Noatak District, Alaska. 31 July igr I.
Figure 3 A. Notes

Same view with long axis of photograph horizontal rather than vertical.

Figure 4 A. Right half of Smith's panoramic view.

Left half of panoramic view. Published together with No. 570 as Plate ${ }_{4} \mathrm{~B}$ in Smith and Mertie (1930).

Glacier is in center background at $c$. ro $\mathrm{km}$. distance. 
One additional glacier photograph (No. 598, Table I) was taken by Smith two weeks later from the north bank of the Noatak River. This photograph shows a small ice cap on Oyukak Mountain (lat. $67^{\circ} 35^{\prime}$ N., long. $155^{\circ} 30^{\prime}$ W.) but it was taken from a distance of nearly Io $\mathrm{km}$. and reveals little detail. Subsequent thinning and recession, if of sufficient magnitude, could probably be measured by comparisons with this photograph, but the writer has not yet had the opportunity to visit the Oyukak Mountain area or the adjacent Noatak.

\section{Camera Stations and Observed Glacier Changes}

Smith's first camera station was located on top of a prominent granite boulder c. $2 \mathrm{~m}$. high which lies at about $980 \mathrm{~m}$. elevation in the valley bottom near Arrigetch Creek (Fig. 2). The boulder is about $100 \mathrm{~m}$. north-west of the present stream margin and $c .0 .7 \mathrm{~km}$. down-valley from the terminus of the recent combined moraine of glaciers $\mathrm{S}_{2}, \mathrm{~A}_{1}$ and $\mathrm{A}_{2}$. The clarity of the foreground detail in the I9 I photographs (Fig. $3 \mathrm{~A}$ ) allowed reproduction

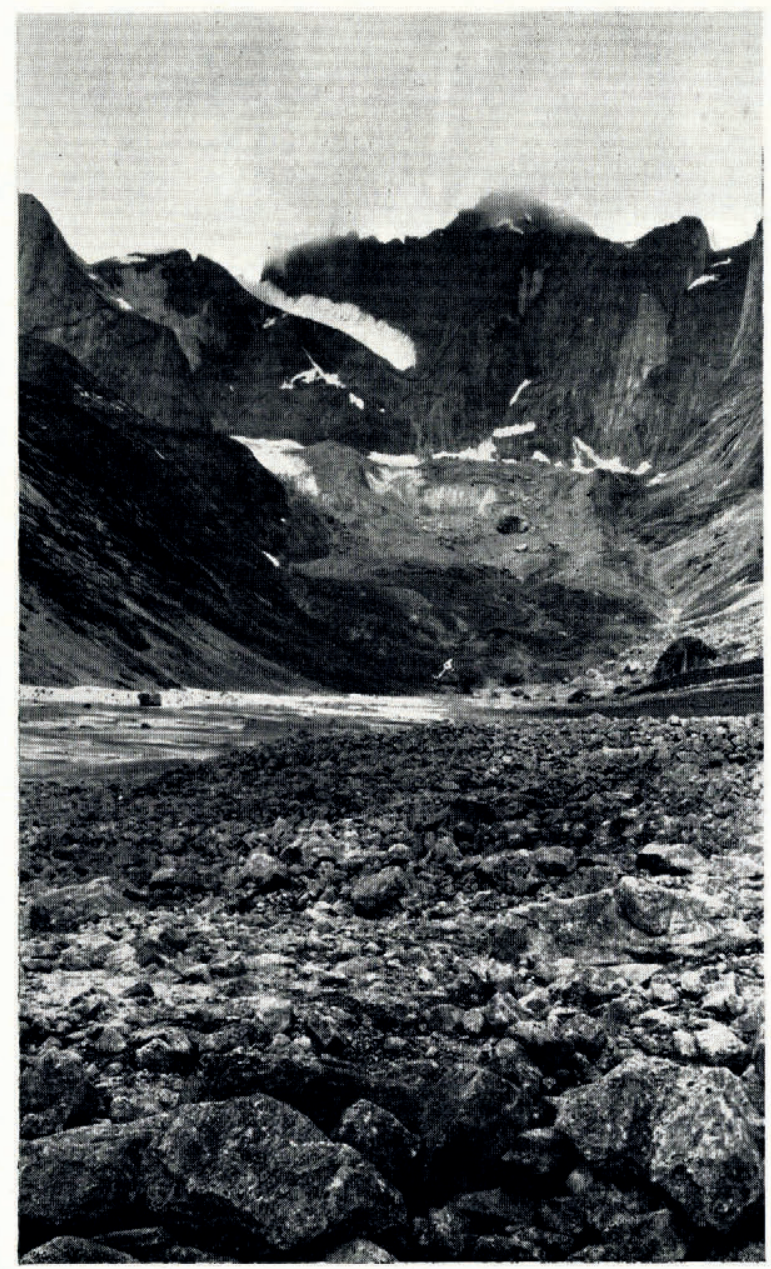

Fig. 3A. Combined terminal moraine of $\mathrm{S}_{2}, \mathrm{Al}_{1}$ and west arm of $\mathrm{A}_{2}$. Older arcuate segment lies at the extreme front and sides; the younger component is on the cirque threshold. (Photograph by P. S. Smith; 567, I6 July I9II) 
of the unmarked camera position to within ${ }_{5} \mathrm{~cm}$. in all three dimensions. Matching photographs (Fig. $3^{B}$ ) taken from this site in 1962 indicate:

(I) The ice-cored moraine in the center of the photographs has lost nearly io per cent of its thickness over the past $5 \mathrm{I}$ yr., decreasing in surface elevation by roughly $20 \mathrm{~m}$.

(2) The instability of this moraine is illustrated by the down-slope movement of nearly all of the larger boulders on its surface. Several boulders actually appear fresher today than they did in Smith's time.

(3) The ice in the head-wall gulley (center background) has thinned appreciably, leaving a pronounced trimline where none was visible in I9I I.

(4) Accumulation of talus along the cliff base (right margin) had increased only slightly, indicating a considerable period of formation prior to $\mathrm{I} 9 \mathrm{I}$ I.

(5) The large boulder in the stream floodplain (near left margin) has neither settled nor

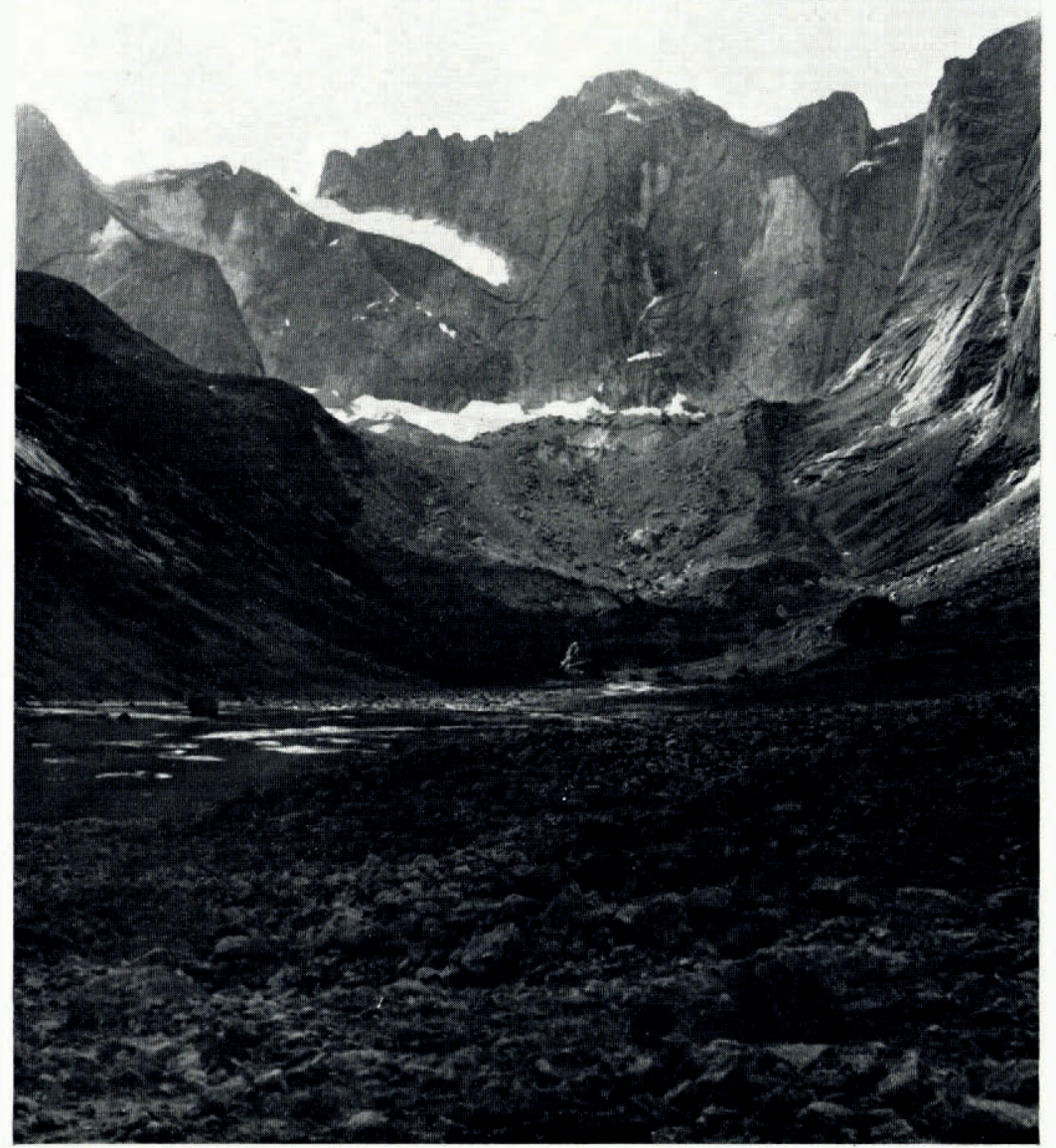

Fig. ${ }_{3}$ B. Same view as in Figure 3 A. (Photograph by T. D. Hamilton, ${ }_{4} 4$ August 1962 , camera station ${ }_{1-62}$ ) 
been covered to any appreciable degree by sediments, reflecting the virtual stability of this area over the past $5^{\mathrm{I}} \mathrm{yr}$.

(6) Lichen cover of the boulders in the foreground has intensified significantly. As most of the foreground boulders in the I9I I photographs are readily identifiable today, they could serve as a good base for lichen growth studies in the area.

Smith's second station was found at $c$. I, $300 \mathrm{~m}$. elevation on a cirque floor just north-west of the recent moraine of $\mathrm{S}_{1}$. The site is located about $300 \mathrm{~m}$. distant (on a bearing of $\mathrm{N}_{22}{ }^{\circ} \mathrm{W}$ ) from the northern tip of a sharp granite ridge which separates this hanging cirque basin from the main valley glacier complex. Alignment of a distinctive fracture in the granite ridge (near right margin, Fig. 4A) with background details permitted re-location of the original camera station to within $55 \mathrm{~cm}$. in all dimensions. Closer positioning was not possible because of the settling and displacement of the foreground boulders which are underlain by ice. Matching photographs (Fig. ${ }_{4} \mathrm{~B}$ ) were taken from the station which, like the other, was then marked with a stone cairn to facilitate future use. Comparison of the rgi i and 1962 photographs shows:

(I) Appreciable recession of both arms of Glacier A2. Present terminal positions are roughly $200 \mathrm{~m}$. farther up-valley and lie at elevations nearly $100 \mathrm{~m}$. higher than in I9II.

(2) Thinning of Wichmann Glacier $\left(\mathrm{A}_{3}\right)$ by an unknown amount. The decrease in surface elevation is indicated by an emerging peak or rock knob (background arrow).

(3) A pronounced trimline (T) near the right margin of Figure ${ }_{4} \mathrm{~B}$ stands $c$. ${ }_{1} 5 \mathrm{~m}$. above the ice surface. No indications of this trimline appear in the earlier photograph.

(4) The ice-cored moraine in the foreground has subsided an average of $2-3 \mathrm{~m}$. from its I9 I I position (dashed line, Fig. $4 \mathrm{~B}$ ). The down-slope movement of its surface boulders indicates continued spilling of boulders over the cirque threshold.

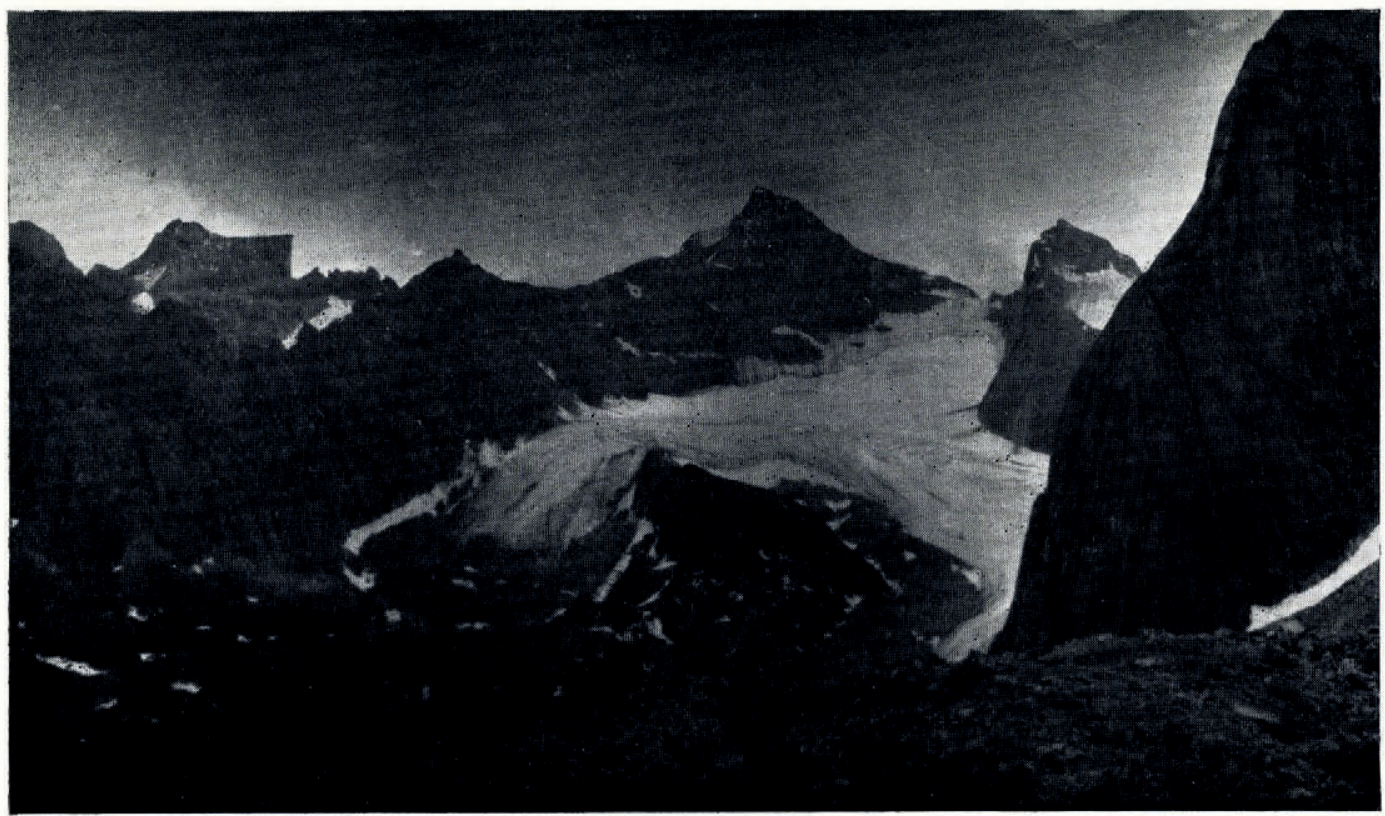

Fig. $4^{A}$. Cirque glacier complex at the head of the north fork of Arrigetch Creek. Note the ice in contact with the younger moraine substage. (Photograph by P. S. Smith; 570,16 July I9II) 


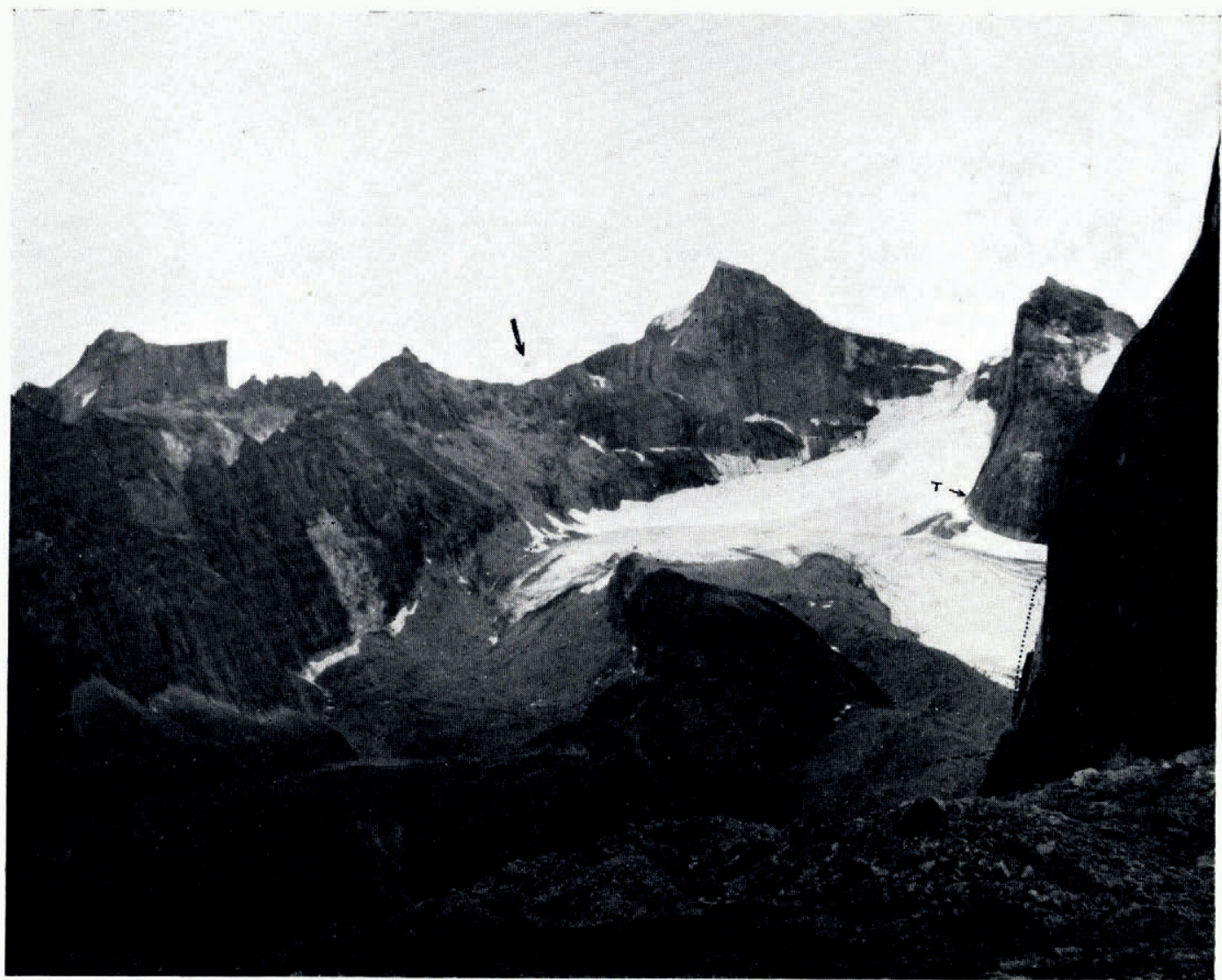

Fig. 4 B. Same view as Figure $4 A$. Note the trimline $(T)$, former position of the ice-cored moraine of $S_{I}$ (dashed line), thinning of Wichmann Glacier (arrow) and modification of the ridge tip (dotted outline). (Photograph by T. D. Hamilton, I4 August 1962 ; camera station $2-62$ )

(5) The snow line on the surface of glacier A2 appears to have moved upward more than I $00 \mathrm{~m}$. since I9I I, but this may be largely due to differences in the dates of the comparative photographs. Smith's photographs were taken in mid-July and the writer's nearly one month later in the summer.

(6) Major rockfalls in at least two places have occurred since I9 I I. One, just down-valley from the eastern terminus of glacier $\mathrm{A}_{2}$, has covered an ice bank at the cliff base and has added considerably to the bulk of the adjacent moraine. A second rock mass (dotted line, Fig. ${ }_{4}$ B) has been removed from the ridge tip near the right margin of the photographs.

\section{Conclusions}

A comparison of 1962 Arrigetch glacier observations with photographs taken $5^{\mathrm{I}} \mathrm{yr}$. earlier indicates a general recession and thinning of ice bodies throughout this area. Recession from the innermost of the recent moraines has been greater since I9I I than in the years before this date, thus either an ice maximum occurred shortly before ig I or the initial recession was relatively slow. Instability of the ice-cored moraines is shown by the general displacements 
of surface debris in recent years. Continued shifting and settling of recent glacial debris is a major problem in precise moraine dating and correlation throughout this region.

Supplementary studies in 1962 and 1963 have shown that the recent moraines often have two components. Inner ridges are generally steeper and less stable, and the 19 I I photographs show ice positions in close proximity to them. The outer moraines, which are still partially ice-cored, are somewhat more stable and vary in position from direct contact with the inner moraines to locations as much as I $\mathrm{km}$. down-valley. This two-stage form is not universal but it was seen in the recent deposits of most of the glaciers that are not spilling their moraines over high cirque thresholds.

The cirque glacier deposits of the Arrigetch Peaks correlate with recent moraines farther north and east in the Brooks Range. They are considered to be the equivalent of the Fan Mountain advance of Detterman and others (1958) and probably with the two-substage Cirque Moraine I and II of Holmes and Lewis (I96I) and the Fan Mountain I and II of Porter (1964). Although no direct dates are yet available for recent moraines in northern Alaska, an initial estimate of mid-eighteenth and middle to late nineteenth centuries may approximate the times of formation of the two substages. A huge body of recent data* from the North Pacific Coast region of North America indicates recent advances culminating during these periods, with generally little evidence of more extensive advances for up to several millennia previously.

\section{Acknowledgements}

Investigations in the Arrigetch Peaks were carried out as parts of field projects sponsored in 1962 by the Arctic Institute of North America (with funds provided by the U.S. Office of Naval Research) and in 1963 by the Geological Society of America. The writer is indebted also to William O. Field of the American Geographical Society for advice and criticisms, and to the U.S. Geological Survey for copies of the early glacier photographs and the loan of Smith's I9I I field notebooks. Copies of the matching photograph sets and supplementary glacial coverage (camera station $\mathrm{I}-63$, Fig. 2) have been placed on file at I.G.Y. World Data Center A. $\dagger$

MS. received 23 June 1964

\section{REFERENCES}

Bray, J. R. 1964. Chronology of a small glacier in eastern British Columbia, Canada. Science, Vol. 144, No. 36r6, p. $287-88$.

Detterman R. L., and others. 1958. Glaciation on the Arctic slope of the Brooks Range, northern Alaska, by R. L. Detterman, A. L. Bowsher and J. T. Dutro, Jr. Arctic, Vol. i I, No. I, p. 43-61.

Harrison, A. E. 1956. Fluctuations of the Nisqually Glacier, Mt. Rainier, Washington, since 1750. Journal of Glaciology, Vol. 2, No. 19, p. 675-76, 680-83.

Heusser, C. J., and Marcus, M. G. 1964. Historical variations of Lemon Creek Glacier, Alaska, and their relationship to the climatic record. Fournal of Glaciology, Vol. 5, No. 37, p. 77-86.

Holmes, G. W., and Lewis, C. R. I961. Glacial geology of the Mount Chamberlin area, Brooks Range, Alaska. (In Raasch, G. O., ed. Geology of the Arctic: proceedings of the first international symposium on Arctic geology held in Calgary, Alberta, January $I_{I-13}$, I96o. Toronto, University of Toronto Press, Vol. 2, p. 848-64.)

Lawrence, D. B. I950. Glacier fluctuation for six centuries in southeastern Alaska and its relation to solar activity. Geographical Review, Vol. 40, No. 2, p. 191-223.

Leffingwell, E. de K. 1919. The Canning River region, northern Alaska. U.S. Geological Survey. Professional Paper

Io9.
Mathews, W. H. I95I. Historic and prehistoric fluctuations of alpine glaciers in the Mt. Garibaldi map-area, southwestern British Columbia. Journal of Geology, Vol. 59, No. 4, p. 357-80.

* For specific studies see Bray (r964), Heusser and Marcus (r964), Sigafoos and Hendricks (I96r), Williams and Ferrians (I96I), Harrison (I956), Matthews (I95I) and Lawrence (1950). A partial tabulation of pertinent dates has been presented by Wright (1962, p. 5).

$\dagger$ I.G.Y. World Data Center A: Glaciology, American Geographical Society, Broadway at 156th Street, New York 32 , N.Y., U.S.A. 
Porter, S. C. 1964. Late Pleistocene glacial chronology of the north-central Brooks Range, Alaska. American Journal of Science, Vol. 262, No. 4, p. 446-6o.

Sable, E. G. I 96 I. Recent recession and thinning of Okpilak Glacier, northeastern Alaska. Arctic, Vol. I4, No. 3, p. $176-87$.

Sigafoos, R. S., and Hendricks, E. L. I961. Botanical evidence of the modern history of Nisqually Glacier, Washington. U.S. Geological Survey. Professional Paper 387-A.

Smith, P. S. r912. Glaciation in northwestern Alaska. Bulletin of the Geological Society of America, Vol. 23, No. 4, p. $563-70$.

Smith, P. S., and Mertie, J. B., jr. 1930. Geology and mineral resources of northwestern Alaska. U.S. Geological Survey. Bulletin 815.

Williams, J. R., and Ferrians, O. J., jr. 1961. Late Wisconsin and Recent history of the Matanuska Glacier, Alaska. Arctic, Vol. 14, No. 2, p. $82-90$.

Wright, H. E., jr. 1962. Glacial geology. (In Proceedings of the conference on the climate of the eleventh and sixteenth centuries. Boulder, Colorado, National Center for Atmospheric Research, p. 5. (NCAR Technical Note 63-I.)) 